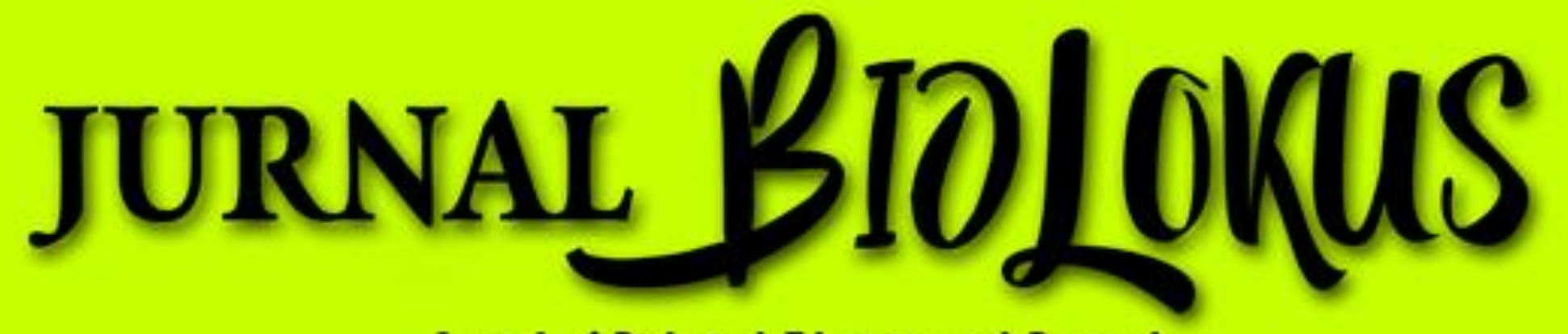

Journal of Biological Education and Research
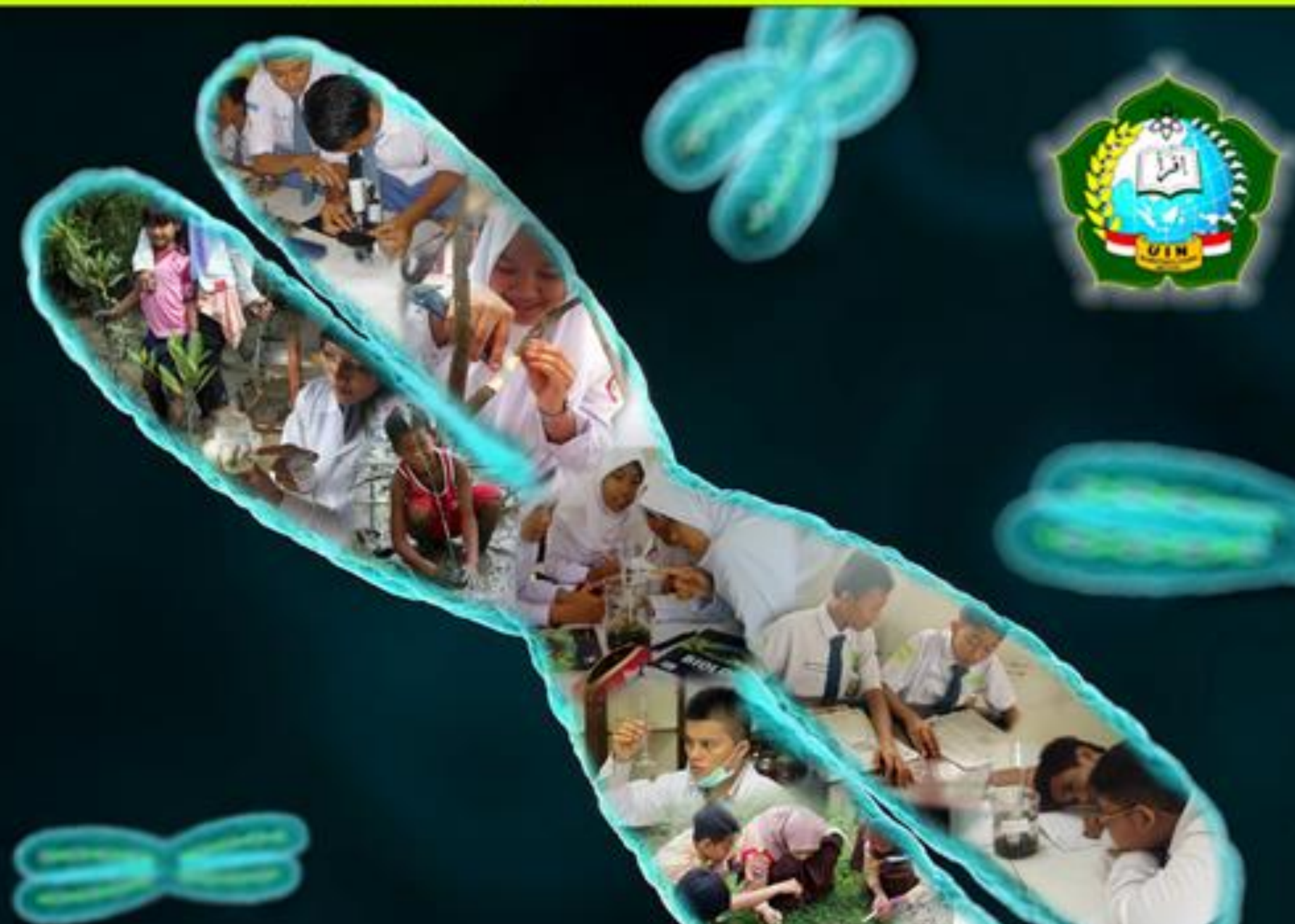


\section{DAFTAR ISI TERBITAN}

$180-185$

186-194

195-201

202-209

210-216

$222-227$

228-233
PENGARUH MODEL PEMBELAJARAN MIND MAPPING TERHADAP HASIL BELAJAR SISWA PADA MATERI RESPIRASI DI KELAS XI SMA NEGERI 2 BILAH HULU

Rahmi Nazliah, Risma Delima Harahap, dan Elysa Rohayani Hasibuan

PENGEMBANGAN MODUL BERORIENTASI PREDICT, OBSERVE, EXPLAIN (POE) PADA MATERI VIRUS TERHADAP KOGNITIF SISWA

Fitri Agustina Lubis dan Ayunda Sabrina Sormin

ANALISIS RENCANA PELAKSANAAN PEMBELAJARAN (RPP) BIOLOGI KURIKULUM 2013 KELAS X SEMESTER 1 TAHUN AJARAN 2016/2017 DI MAS ISLAMIYAH GUNTING SAGA KUALUH SELATAN KABUPATEN LABUHANBATU UTARA

Risma Delima Harahap dan Rahmi Nazliah EFEKTIVITAS PENERAPAN MODEL PEMBELAJARAN TGT (TEAMS GAMES TOURNAMENTS) TERHADAP PRESTASI BELAJAR BIOLOGI PADA SISWA KELAS XII MIA-5 MAN 3 MEDAN

Satriawati MENINGKATKAN KOMPETENSI PROFESIONAL GURU DALAM
MENYUSUN RENCANA PELAKSANAAN PEMBELAJARAN KURIKULUM
2013 MELALUI WORKSHOP DI SMP SWASTA AMANDA
Henny Ramdaniar

MENINGKATKAN HASIL BELAJAR SISWA PADA PELAJARAN ILMU PENGETAHUAN ALAM DI KELAS VII-2 MELALUI PENDEKATAN PEMBELAJARAN CARA BELAJAR SISWA AKTIF DI SMP NEGERI 29 MEDAN Sauli Farida Siregar MENINGKATKAN KEMAMPUAN KEPALA SEKOLAH DALAM MENGELOLA SEKOLAH MELALUI WORKSHOP TOTAL QUALITY MANAGEMENT DAN SUPERVISI MANAJERIAL DI SMP BINAAN

Arizona

PENINGKATAN KEMAMPUAN BERPIKIR KRITIS SISWA MELALUI MODEL PEMBELAJARAN KOOPERATIF THINK PAIR SHARE

DI KELAS X SMA NEGERI 4 PADANGSIDIMPUAN

Heni Mulyani Pohan dan Ade Isma Hasibuan 


\title{
MENINGKATKAN HASIL BELAJAR SISWA PADA PELAJARAN ILMU PENGETAHUAN ALAM DI KELAS VII-2 MELALUI PENDEKATAN PEMBELAJARAN CARA BELAJAR SISWA AKTIF DI SMP NEGERI 29 MEDAN
}

\author{
Sauli Farida Siregar (saulifaridasiregar@yahoo.com) \\ SMP Negeri 29 Medan \\ Jalan Benteng Hilir Kecamatan Medan Tembung Kota Medan Provinsi Sumatera Utara
}

\begin{abstract}
ABSTRAK
Tujuan penelitian untuk meningkatkan hasil belajar siswa pada pelajaran Ilmu Pengetahuan Alam di Kelas VII-2 melalui pendekatan pembelajaran cara belajar siswa aktif di SMP Negeri 29 Medan Tahun Pelajaran 2016/2017. Metode penelitian yang digunakan dalam penelitian adalah Metode Penelitian Tindakan Kelas dengan menggunakan 2 siklus. Subjek penelitian ini adalah siswa Kelas VII-2 SMP Negeri 29 Medan sebanyak 36 orang. Instrumen pengumpulan data yang digunakan untuk memperoleh data dalam penelitian ini adalah menggunakan test, angket dan observasi. Teknik analisa data menggunakan perhitungan jumlah nilai yang diperoleh siswa dibagi jumlah nilai total dikalikan dengan seratus kemudian perhitungan data menggunakan pengelompokan nilai rata-rata siswa, persentase siswa yang tuntas dan persentase jumlah siswa yang belum tuntas. Hasil Penelitian menunjukkan terdapat peningkatan hasil belajar dengan menerapkan pendekatan pembelajaran cara belajar siswa aktif dengan hasil sebagai berikut: (1) terdapat peningkatan rata-rata hasil belajar siswa, dimana pada tes awal ratarata hasil belajar siswa adalah 41,67, pada siklus I meningkatkan menjadi 61,67 kemudian pada siklus II meningkat lagi menjadi 77,5, terdapat peningkatan jumlah siswa yang tuntas, dimana pada tes awal jumlah siswa yang tuntas hanya 0\%, meningkat menjadi 52,78\% pada siklus I kemudian meningkat lagi menjadi $86,11 \%$ pada siklus II, terdapat penurunan jumlah siswa yang tidak tuntas, dimana pada tes awal jumlah siswa yang tidak tuntas mencapai $100 \%$, pada siklus I menurun menjadi $47,22 \%$ kemudian pada siklus II menurun lagi menjadi 13,89\% dengan kata lain hanya 5 siswa saja yang memperoleh nilai 60 dan selebihnya (31) siswa memperoleh nilai di atas 70.
\end{abstract}

Kata Kunci : Hasil belajar, pendekatan pembelajaran cara belajar siswa aktif

\begin{abstract}
The aim of this study is to improve of student achievement on Science at class VII-2 through the active learning approach at SMP Negeri 29 Medan in 2017/2018 academic year. The method of this study is classroom action research by using two cycles. The subject of this study is the students of VII-2 grade SMP Negeri 29 Medan. There are 36 students. The techniques to collecting data are test, questioner and observation. The range score for test is 1-100. The technique of analysing data is to to count the average of percentage of the students who pass the standard minimal score and yet. The resullt of the study are: (1) There are the increasing average of students achivement, where pre-test is 41,67, at first cycle is increasing to 61,67 and the second cycle is increasing to 77,5. There are the increasing of the amount of students who pass the test, at the pre-test the students who pass the test is $0 \%$, and the first cycle it tobe $52,78 \%$ and the second cycle is to be $86,11 \%$. There are the decreasing of the students who fail the test. At pre-test there $100 \%$ students are fail and at first cycle is decreasing to be $47,22 \%$ and at second cycle is tobe $13,89 \%$. On the other hand There are only 5 students who get the score under 70 and 31 students get score more than 70.
\end{abstract}

Keywords : Students achievement, active learning approach

\section{PENDAHULUAN}

Penerapan pendekatan ataupun strategi pembelajaran dalam proses pembelajaran di dalam kelas adalah sangat penting karena dengan penerapan pendekatan pembelajaran yang sesuai dengan peserta didik akan dapat meningkatkan motivasi belajar siswa yang pada akhirnya dapat meningkatkan hasil belajar siswa. Pendekatan pembelajaran adalah suatu pendekatan untuk membuat proses pembelajaran menjadi inovatif, kreatif dan bermutu.

Guru yang menerapkan pendekatan pembelajaran yang sesuai akan membawa suasana belajar yang menyenangkan dan memungkinkan 
siswa untuk mengembangkan kreatifitas. Suasana belajar yang menyenangkan akan membawa dampak pada motivasi belajar dan disiplin yang meningkat. Motivasi belajar yang tinggi menjadi salah satu faktor penentu keberhasilan siswa dalam mencapai hasil belajar yang terbaik.

Jika tidak ada kesesuaian antara kondisi siswa dan materi yang akan diajarkan, maka proses belajar mengajar akan menjadi seadanya saja dan terkesan monoton dan membosankan, sehingga keaktifan dan kreatifitas siswa tidak akan mampu dikembangkan secara maksimal, sehingga hasil belajar yang diharapkan tidak akan tercapai menurut Wirtha \& Rapi dalam Tarigan (2008). Aunurrahman (2012) mengungkapkan bahwa penggunaan model pembelajaran yang tepat dapat memudahkan siswa untuk memahami pelajaran sehingga memungkinkan siswa mencapai hasil belajar yang baik.

Berdasarkan hasil pengamatan di Kelas VII-2 mata pelajaran IPA di SMP Negeri 29 Medan, proses belajar mengajar di kelas masih dilakukan dengan menerapkan metode konvensional (ceramah). Ketika proses pembelajaran tersebut berlangsung, banyak siswa yang tidak memperhatikan gurunya sehingga kreatifitas siswa tidak terbangun, kemandirian dalam kegiatan pembelajaran pun sedikit sekali terlihat. Ketekunan yang dimiliki belum tampak. Selain itu hanya ada beberapa siswa yang aktif di kelas, mereka mengajukan beberapa pertanyaan yang berkaitan dengan materi yang telah diajarkan, namun masih banyak siswa yang hanya menjadi pendengar dan tergolong pasif di kelas. Saat mendapatkan nilai yang tidak memuaskan seakan menjadi hal yang biasa bagi siswa. Siswa tidak termotivasi dalam melakukan kegiatan pembelajaran. Untuk dapat menciptakan proses pembelajaran yang berpusat kepada siswa, guru harus memiliki kompetensi.

Salah satu kompetensi yang harus dimiliki oleh guru adalah memahami dan menerapkan pendekatan pembelajaran. Namun pada kenyataannya guru belum mampu menerapkan pendekatan pembelajaran yang berpusat kepada siswa. Selama ini guru belum menerapkan pendekatan pembelajaran yang dapat meningkatkan hasil belajar siswa dan dapat meningkatkan minat serta keaktifan siswa dalam mengikuti pelajaran di dalam kelas. Kemudian ditemukan juga masalah rendahnya kualitas pembelajaran Ilmu Pengetahuan Alam dan rendahnya hasil belajar siswa untuk mata pelajaran Ilmu Pengetahuan Alam. Pendekatan pembelajaran yang berpusat pada siswa adalah pendekatan cara belajar siswa aktif. Pendekatan pembelajaran ini dapat meningkatkan minat siswa dan hasil belajar siswa.

\section{Hakekat Hasil Belajar}

Menurut Sudjana (2010: 22) hasil belajar adalah kemampuan yang dimiliki siswa setelah menerima pengalaman belajar. Hasil dari kegiatan belajar ditandai dengan adanya perubahan perilaku ke arah positif yang relatif permanen pada diri orang yang belajar. Sesorang dapat dikatakan telah berhasil dalam belajar jika ia mampu menunjukkan adanya perubahan dalam dirinya. Perubahan-perubahan tersebut di antaranya dari segi kemampuan berpikirnya, keterampilannya, atau sikapnya terhadap suatu objek.

Hamdani (2011:12) bahwa hakekat hasil belajar adalah suatu perubahan pada individu yang belajar, tidak hanya mengenai pengetahuan, tetapi juga membentuk kecakapan dan penghayatan dalam diri pribadi individu untuk belajar.

Jika dikaji lebih mendalam, maka hasil belajar dapat tertuang dalam taksonomi Bloom, yakni dikelompokkan dalam tiga ranah (domain) yaitu domain kognitif atau kemampuan berpikir, domain afektif atau sikap, dan domain psikomotor atau keterampilan. Kemampuan hasil belajar menjadi lima macam antara lain: (1) hasil belajar intelektual merupakan hasil belajar terpenting dari sistem lingsikolastik; (2) strategi kognitif yaitu mengatur cara belajar dan berfikir seseorang dalam arti seluas-luasnya termaksuk kemampuan memecahkan masalah; (3) sikap dan nilai, berhubungan dengan arah intensitas emosional dimiliki seseorang sebagaimana disimpulkan dari kecenderungan bertingkah laku terhadap orang dan kejadian; (4) informasi verbal, pengetahuan dalam arti informasi dan fakta; dan (5) keterampilan motorik yaitu kecakapan yang berfungsi untuk lingkungan hidup serta memprestasikan konsep dan lambang (Sudjana, 2010: 24).

\section{Hakekat Pendekatan Pembelajaran}

Secara umum, pendekatan dapat diartikan sebagai suatu upaya yang dilakukan oleh seseorang atau organisasi untuk sampai pada tujuan. Dalam Kamus Besar Ilmu Pengetahuan Alam pendekatan adalah rencana yang cermat 
mengenai kegiatan untuk mencapai sasaran khusus (Hamdani, 2011: 18) berpendapat bahwa yang dimaksud pendekatan adalah suatu prosedur yang digunakan untuk memberikan suasana yang kondusif kepada siswa dalam rangka mencapai tujuan pembelajaran.

\section{Hakekat Pembelajaran}

Menurut aliran behavioristik, pembelajaran adalah usaha guru membentuk tingkah laku yang diinginkan dengan menyediakan lingkungan atau stimulus. Aliran kognitif mendefinisikan pembelajaran sebagai cara guru memberikan kesempatan kepada siswa untuk berpikir agar mengenal dan memahami sesuatu yang sedang dipelajari (Hamdani, 2011:23).

\section{Pendekatan Pembelajaran Cara Belajar Siswa Aktif (CBSA)}

Siswa pada hakekatnya memiliki potensi atau kemampuan yang belum terbentuk secara jelas, maka kewajiban guru untuk merangsang agar mereka mampu menampilkan potensi itu. Para guru dapat menumbuhkan keterampilanketerampilan pada siswa sesuai dengan taraf perkembangannya, sehingga mereka memperoleh konsep. Dengan mengembangkan keterampilanketerampilan memproses perolehan, siswa akan mampu menemukan dan mengembangkan sendiri fakta dan konsep serta mengembangkan sikap dan nilai yang dituntut. Proses belajar-mengajar seperti inilah yang dapat menciptakan siswa belajar aktif. Hakekat dari CBSA adalah proses keterlibatan intelektual-emosional siswa dalam kegiatan belajar mengajar yang memungkinkan terjadinya:

- Proses asimilasi/ pengalaman kognitif, yaitu: yang memungkinkan terbentuknya pengetahuan.

- Proses perbuatan/ pengalaman langsung, yaitu: yang memungkinkan terbentuknya keterampilan.

- Proses penghayatan dan internalisasi nilai, yaitu: yang memungkinkan terbentuknya nilai dan sikap.

Walaupun demikian, hakekat CBSA tidak saja terletak pada tingkat keterlibatan intelektualemosional, tetapi terutama juga terletak pada diri siswa yang memiliki potensi, tendensi atau kemungkinan kemungkinan yang menyebabkan siswa itu selalu aktif dan dinamis. Oleh sebab itu guru diharapkan mempunyai kemampuan profesional sehingga ia dapat menganalisis situasi instruksional kemudian mampu merencanakan sistem pengajaran yang efektif dan efisien. Dalam menerapkan konsep CBSA, hakekat CBSA perlu dijabarkan menjadi bagian-bagian kecil yang dapat kita sebut sebagai prinsip-prinsip CBSA sebagai suatu tingkah laku konkrit yang dapat diamati. Dengan demikian dapat kita lihat tingkah laku siswa yang muncul dalam suatu kegiatan belajar mengajar (Raka, 1992: 15).

\section{METODE PENELITIAN}

Penelitian ini dilaksanakan pada SMP Negeri 29 Medan Jalan Benteng Hilir Kecamatan Medan Tembung Kota Medan Provinsi Sumatera Utara. Adapun waktu penelitian ini dilaksanakan selama 6 bulan, yakni mulai dari bulan Januari 2017 sampai Juni 2017. Subjek pada penelitian ini adalah siswa Kelas VII-2 semester II (genap) Tahun Pelajaran 2016/2017 di SMP Negeri 29 Medan dengan jumlah siswa sebanyak 36 orang.

Metode yang digunakan dalam penelitian ini adalah Metode Penelitian Tindakan Kelas dengan menggunakan 2 siklus, dimana masing-masing siklus terdiri dari: perencanaan, pelaksanaan, evaluasi dan refleksi (Arikunto, 2010: 6).

Teknik pengumpulan data yang digunakan dalam penelitian ini adalah menggunakan: (1) angket, (2) tes dan (3) observasi. Angket digunakan untuk mengumpulkan data tentang minat siswa, kemudian tes digunakan untuk menjaring data siswa, kemudian tes digunakan untuk menjaring data tentang hasil belajar siswa dan observasi digunakan untuk menjaring data tentang keaktifan siswa dalam proses belajar mengajar.

Teknik analisa data yang digunakan adalah menggunakan perhitungan jumlah nilai yang diperoleh siswa dibagi jumlah nilai total dikalikan dengan seratus kemudian perhitungan data menggunakan pengelompokan nilai rata-rata siswa, persentase jumlah siswa yang tuntas dan persentase jumlah siswa yang tidak tuntas.. Evaluasi hasil belajar siswa diberi rentang nilai dari 0 - 100 untuk menentukan tingkatan prestasi belajar siswa kemudian untuk angket minat siswa di analisa berdasarkan jumlah jawaban siswa yang menjawab "ya" atau "tidak". Apabila 80\% dari indikator minat siswa dijawab "Ya" maka dinyatakan siswa memiliki minat yang tinggi.

Indikator kinerja dalam penelitian ini adalah jika 80\% siswa memperoleh nilai sama dengan 70 atau lebih dan $80 \%$ siswa aktif dalam kegiatan 
belajar mengajar, maka penelitian sudah jenuh sehingga tak perlu dilanjutkan ke siklus berikutnya.

\section{HASIL DAN PEMBAHASAN Siklus I}

Berdasarkan perolehan data di atas memang terjadi peningkatan hasil belajar antara tes awal dengan siklus I yakni: (1) pada tes awal rata-rata hasil belajar adalah 41,67 sedangkan pada siklus I menjadi 61,67 (2) pada tes awal jumlah ketuntasan siswa adalah $0 \%$ sedangkan pada siklus I menjadi $52,78 \%$ dan (3) jumlah siswa yang belum tuntas pada tes awal adalah $100 \%$ sedangkan pada siklus I jumlah siswa yang belum tuntas berkurang menjadi $47,22 \%$. Oleh karena jumlah siswa yang tuntas belum mencapai $80 \%$ (masih 52,78\%) maka perlu dilanjutkan ke siklus berikutnya yakni siklus II.

\section{Siklus II}

Siswa yang memperoleh nilai 70 ke atas mencapai $86,11 \%$ (31 siswa) dan jumlah siswa yang memperoleh nilai 70 ke bawah hanya 13,89\% (hanya 5 siswa). Ini berarti penelitian telah berhasil karena indikator kinerja yang ditetapkan adalah $80 \%$ siswa memperoleh nilai 70 ke atas sedangkan pada siklus II ini siswa yang memperoleh nilai 70 ke atas mencapai $86,11 \%$. Ini berarti penelitian tidak perlu dilanjutkan ke siklus berikutnya.

Berdasarkan data hasil belajar siswa, penerapan CBSA dapat meningkatkan hasil belajar siswa. Hal ini dapat dilihat dari hasil belajar siswa pada siklus I dan siklus II berikut :

- Terdapat peningkatan rata-rata hasil belajar siswa, dimana pada tes awal rata-rata hasil belajar siswa adalah 41,67, pada siklus I meningkatkan menjadi 61,67 kemudian pada siklus II meningkat lagi menjadi 77,5.

- Terdapat peningkatan jumlah siswa yang tuntas, dimana pada tes awal jumlah siswa yang tuntas hanya $0 \%$, meningkat menjadi $52,78 \%$ pada siklus I kemudian meningkat lagi menjadi $86,11 \%$ pada siklus II.

- Terdapat penurunan jumlah siswa yang tidak tuntas, dimana pada tes awal jumlah siswa yang tidak tuntas mencapai $100 \%$, pada siklus I menurun menjadi $47,22 \%$ kemudian pada siklus II menurun lagi menjadi 13,89\% dengan kata lain hanya 5 siswa saja yang memperoleh nilai 70 ke bawah dan selebihnya (31) siswa memperoleh nilai di atas 70 . Hal tersebut di atas dapat dilihat pada Gambar 1.

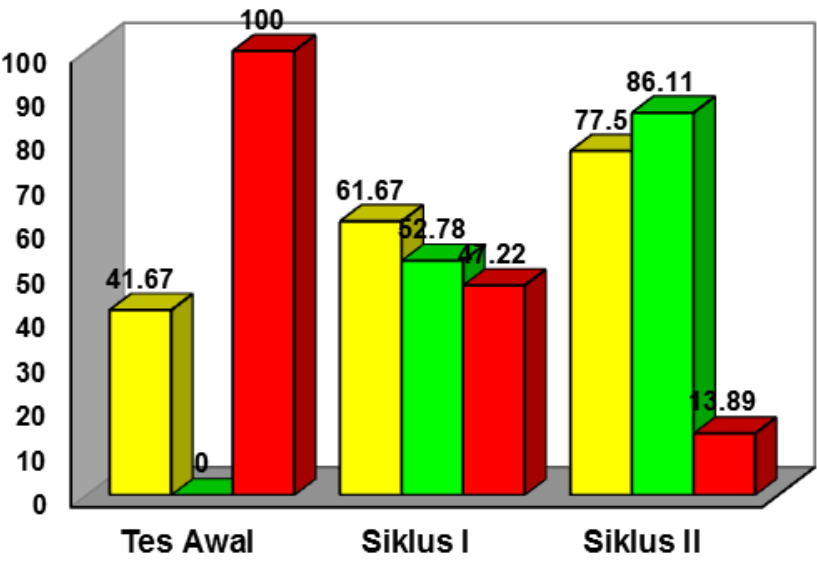

Gambar 1.Hasil Belajar, Tes Awal, Siklus I, Siklus II Keterangan:

$\begin{array}{ll}\text { Kuning } & =\text { Rata-rata } \\ \text { Hijau } & =\text { Tuntas } \\ \text { Merah } & =\text { Tidak Tuntas }\end{array}$

\section{SIMPULAN}

Berdasarkan hasil belajar siswa di atas, maka disimpulkan bahwa: Hasil belajar siswa yang diajar menggunakan Pendekatan Pembelajaran Cara Belajar Siswa Aktif dapat meningkat, terdapat peningkatan rata-rata hasil belajar siswa, dimana pada tes awal rata-rata hasil belajar siswa adalah 41,67 , pada siklus I meningkatkan menjadi 61,67 kemudian pada siklus II meningkat lagi menjadi 77,5 , terdapat peningkatan jumlah siswa yang tuntas, dimana pada tes awal jumlah siswa yang tuntas hanya $0 \%$, meningkat menjadi $52,78 \%$ pada siklus I kemudian meningkat lagi menjadi $86,11 \%$ pada siklus II, terdapat penurunan jumlah siswa yang tidak tuntas, dimana pada tes awal jumlah siswa yang tidak tuntas mencapai $100 \%$, pada siklus I menjadi $47,22 \%$ kemudian pada siklus II menurun lagi menjadi $13,89 \%$ dengan kata lain hanya 5 siswa saja yang memperoleh nilai 60 dan 70 dan selebihnya (31) siswa memperoleh nilai di atas 70 .

\section{REFERENSI}

Arikunto, Suharsimi (2010). Penelitian Tindakan Kelas. Jakarta: Rieneka Cipta.

Aunurrahman. (2012). Belajar dan Pembelajaran. Bandung: Alfabeta.

Djamarah, S. (2002), Strategi Belajar Mengajar. Jakarta: Rineka Cipta. 
Sauli F. Siregar, Meningkatkan Hasil Belajar Siswa Pada Pelajaran Ilmu Pengetahuan Alam..

JURNAL BIOLOKUS Vol.2 (2)

Hamdani. (2011). Pendekatan Belajar Mengajar.

Bandung: Pustaka Setia.

Kemdikbud. (2012). Pedoman Penilaian Hasil Belajar. Jakarta. Kemdikbud.

Raka, Joni. (1992). Pendekatan Pembelajaran. Jakarta: Bumi Aksara.

Sanjaya, Wina. (2011). Pendekatan Pembelajaran Berorientasi Standar Proses Pendidikan. Jakarta: Kharisma Putra Utama.

Silberman, M. L. (2013). Active Learning 101 Cara Belajar Siswa Aktif. Jakarta: Nusa Media.

Sudjana, Nana. (2010). Dasar-Dasar Proses Belajar, Bandung : Sinar Baru.

Sugandi, A. (2004). Teori Pembelajaran. Semarang: UPT MKK Universitas Negeri Malang.

Tarigan, M.R.M., Purnama, D.A., Munir, M., Azwar, E. (2019). PENGARUH MODEL ACTIVE DEBATE TERHADAP HASIL BELAJAR SISWA PADA MATERI EKOSISTEM DI KELAS X MADRASAH ALIYAH SWASTA PROYEK UNIVA MEDAN. Jurnal Biolokus. 2 (1): 139-145. 